\title{
Comparative analysis of extension services of agricultural development programme in Edo and Osun States, Nigeria
}

\author{
Ogunsumi, L. O. ${ }^{1}$, A. J. Farinde ${ }^{2}$ and G.C. Alonge ${ }^{1}$ \\ ${ }^{1}$ Institute of Agricultural Research and Training, Obafemi Awolowo University \\ P.M.B. 5029, Ibadan, Nigeria \\ ${ }^{2}$ Department of Agricultural Extension and Rural Development Obafemi Awolowo University, \\ Ile-Ife, Nigeria.
}

\begin{abstract}
This study compares the extension activities of Agricultural Development Programmes of Osun and Edo States. A multi-state random sampling method was used in selecting zones blocks, cells and the farmers. And interview schedule was designed to obtain data on the respondents demographic characteristics and extension activities. Data were gathered from 160 farmers from the two states. The result shows that majority of the farmers in both states have been farming for more than 6 years but Osun State has more experienced farmers than Edo State. In both states rentage and purchase accounted for about $26.3 \%$ of farm land. The study also shows that Osun State ADP rendered farm services more than Edo State in relation to equipment, but in Edo State most farmers get equipment from the Ministry of Agriculture and Public Hiring Unit. Farmers from Osun State intensively cultivate and have larger farms than Edo State. Farmers in both states acknowledged the assistance of ADP in the supply of improved planting materials and other inputs. In the area of infrastructure (Construction of dams roads processing unit and bore holes) both farmers and enclave communities benefited. T- test analysis shows that there is no significant difference between the extension services of the two states $(t=3.71, P>0.05)$.
\end{abstract}

Keywords: extension services, Agricultural development, comparative analysis

\section{INTRODUCTION}

The agricultural industry which for several decades was the mainstay of the economy in terms of its contribution to the gross domestic product, export earnings, food and employment has not been growing appreciably in recent years. The growth of agriculture is less in food crops and livestock sector than in export crops (Adegeye and Dittoh, 1985).

In most of the Third World Countries of which Nigeria is one, agriculture stands as the most crucial factor in economic development. This assertion cannot be regarded as an over statement taking into consideration the proportion of population involved directly in farming and the fact that most, if not all of the food and raw materials, are derived from agriculture (Taiye, 1994). The government over the years has always realized that for meaningful economic development to take place, there must be agricultural development. Effort must be geared towards developing the small-scale farmers since Nigerian Agriculture is largely peasant in nature.

The Federal Government of Nigeria in an effort to encourage agricultural development formulated several policies, launched several programmes and established several agricultural institutions (Egbarevba, 1996). Some of such programmes include the National Accelerated Food Production. The Nigerian Agricultural Development Programmes (ADPs) began as enclave ADPs in Gombe, Gusua, Funtua, Bida, Ekiti Akoko, Lafia Ayangba, Ilorin and Oyo North in the mid 1970s. They were employed the training and visit ( $T \& V$ ) system of agricultural extension (Adedipe et al, 1995, Adebayo and Idowu, 2000).

ADP system was based on the belief that increased food production cannot be achieved unless the right technology is available, an effective extension system exists and free access to inputs, adequate market and other infrastructural facilities. The ability to maintain these various factors - rural roads and water supply, farm inputs, under a single management, mark the ADP system out as distinct from the smallscale farmers (Onaghise, 1991 and Bola 1993). However, the Agricultural Development Programmes (ADPs) in Nigeria have shown concrete proofs of its worth as a successful programe of agricultural transformation through a revitalized agricultural extension effort (World Bank, 1995, Adedipe et al, 1995 and Adebayo and Idowu 2000). 
Given this background the following objectives become relevant

1. Identity the demographic characteristics of the farms families in the study areas

2. Compare the source of inputs of the farm families in the study area

3. Compare the impact of infrastructure available to farmers in the study area

The hypothesis for this study is therefore stated below in a null form

There is no significant difference between the extension services by ADP to farmers in both Edo and Osun States.

\section{METHODOLOGY}

The study was carried out in Edo and Osun State Agricultural Development Programme i.e. OSSADEP and EDOSADEP. A multi-stage random sampling method was employed. Two zones were selected from each of the states, for OSSADEP (Iwo zone and ljesha/lfe zones) and for EDOSADEP Edo South (Benin) and Edo North (Irua). Two blocks were selected from each of the zones. Iwo zone (Iwo and Ejigbo block) and ljesha/lfe zone (llesha and ljebujesha blocks) while Edo South (Ikopba and Okha blocks) Edo North (Igueben and Ekpoma blocks). Two cells were selected from each of the blocks and 10 contact farmers were selected from each cell. A total of 80 farmers were selected from each state and 160 farmers were interviewed from two states (BENDEL ADP, 1989 and OSUN ADP, 1999).

Date analysis: Both descriptive and inferential statistics were used such as means percentage and T - test.

Table 1:

Multi- State Sampling Procedure of the Study Area

\begin{tabular}{|l|l|l|l|l|l|l|l|}
\hline \multicolumn{9}{|c}{ Osun State } & \multicolumn{5}{c|}{ Edo State } \\
\hline Zones & Block & Cell & Farmers & Zones & Block & Cell & Farmers \\
\hline Iwo & Iwo & Labo & 10 & Edo North & Igueben & Iduowina & 10 \\
& & Ago Ireti & 10 & Irua & & Igure & 10 \\
\hline & & Isundurin & 10 & & Ekpoma & Oban & 10 \\
\hline & Ejigbo & Aato & 10 & & & Igunole & 10 \\
\hline & & Igangan & 10 & Edo State & Ikopoba & Ugoneki & 10 \\
\hline Ilesa/lfe & Ilesha & Biladu & 10 & & (Benin) & Ogonoba & 10 \\
\hline & & ljeda & 10 & & Okha & Idogbo & 10 \\
\hline & Ijebu-Jesha & Era & 10 & & & Obagei & 10 \\
\hline & \multicolumn{2}{|c|}{$\mathbf{8 0}$} & & & & $\mathbf{8 0}$ \\
\hline
\end{tabular}

\section{RESULTS AND DISCUSSION}

Status of the Farmers in Edo and Osun States : The farmers interviewed in both states are full of times basis, majority of them have been farming for more than 6 years.

From table 2 data shows that Osun State has more experienced farmers.

Up to $80 \%$ of the farmers in the study area have 4 ha of farm land and above. Subsistence farming in high forest zone on government land is rampant in Edo State.
In both states, both rentage and direct purchase account for about $26.3 \%$ of farm land (Table 3 ).

Osun State ADP renders farm services more than Edo State in relation to equipment. Also in Edo State most farmers get their equipment from Ministry of Agriculture and Public Hiring Units.

Table 5 reveals that majority of materials for planting are obtained in both states through ADP. However, few farmers in Edo State still rely on reserve from previous harvest and purchase from open market. 
Table 2: $\quad$ Farmer's Status in Edo and Osun State

\begin{tabular}{|l|c|c|c|c|}
\hline Variables & Edo State & \multicolumn{2}{c|}{ Osun State } \\
\hline & Freq. & 100 & \multicolumn{2}{c|}{ Preq. } \\
\hline Full time farmers & 80 & - & Nil & \\
\hline Part time farmers & Nil & & & \\
\hline Duration in Farming & & - & Nil & \\
\hline$<$ 3yrs & Nil & 26 & 5 & - \\
\hline $4-6 y r s$ & 20 & 31.3 & 15 & 6.3 \\
\hline $7-10 y r s$ & 25 & 43.8 & 60 & 18.8 \\
\hline$>10$ yrs & 35 & 100 & 80 & 75.0 \\
\hline Total & 80 & & & 100 \\
\hline
\end{tabular}

Table 3: Variables

Variables

\begin{tabular}{|l|r|}
\hline Farm Size & \\
\hline$<1 \mathrm{Ha}$ & 2 \\
\hline $2-3 \mathrm{Ha}$ & \\
\hline $4-5 \mathrm{Ha}$ & \\
\hline$>5 \mathrm{Ha}$ & 4 \\
\hline Source of Land & \\
\hline Inherited & \\
\hline
\end{tabular}

Rentage

Direct purchase 7

Lease from Govt.

Forest area

Total

and Source of Land for Faming of Farmers in Edo and Osun State ADP
\begin{tabular}{|l|l|r|l|}
\hline \multicolumn{3}{c|}{ Osun State } \\
\hline Freq. & \multicolumn{3}{|c|}{ Freq. Percentage } \\
\hline 2 & 12.5 & 2 & 2.5 \\
\hline 5 & 6.3 & 3 & 3.8 \\
\hline 25 & 31.3 & 5 & 6.3 \\
\hline 40 & 50 & 70 & 87.5 \\
\hline & & & 31.5 \\
\hline 23 & 28.8 & 25 & 25.0 \\
\hline 5 & 6.3 & 20 & 31.3 \\
\hline 8.8 & 10 & 12.5 & \\
\hline 45 & 56.3 & 25 & 100 \\
\hline & & 80 & \\
\hline 80 & 100 & & \\
\hline
\end{tabular}

Table 4: Sources of Tractors other Equipment by farmers in Edo and Osun States

\begin{tabular}{|l|l|l|l|l|}
\hline Variables & \multicolumn{1}{|c|}{ Freq. } & \multicolumn{1}{|c|}{ Preq. } \\
\hline From ADP & 30 & 37.5 & 65 & 81.3 \\
\hline Ministry & 20 & 25.0 & 10 & 12.5 \\
\hline Farm Settlement & - & - & - & \\
\hline Public Hiring & 10 & 12.5 & 5 & 6.3 \\
\hline $\begin{array}{l}\text { Improved Hybrid Seed } \\
-\end{array}$ & - & & - & - \\
\hline
\end{tabular}

Table 5:

Sources of Planting Materials for Farmers In Edo and Osun States

\begin{tabular}{|c|c|c|c|c|c|c|}
\hline \multicolumn{3}{|l|}{ Variables } & Edo State & & & Osun State \\
\hline & \multicolumn{2}{|c|}{ Freq. } & Percentage & & Freq. & Percentage \\
\hline Supply from ADP & \multicolumn{2}{|c|}{70} & 87.5 & & 80 & 100 \\
\hline Ministry of Agriculture & Nil & - & & Nil & - & \\
\hline Purchase from market & 5 & 6.3 & & Nil & - & \\
\hline Reserve from previous & 5 & 6.3 & & Nil & - & \\
\hline \multicolumn{7}{|l|}{ Years harvest } \\
\hline Improved Hybrid Seed & - & - & & - & & \\
\hline
\end{tabular}


Table 6: Supply of chemicals and handling in both states in 1999

Supply of chemical (fertilizer/pesticides) to farmers in Edo and Osun States

\begin{tabular}{|l|l|l|l|l|}
\hline Variables & & Edo State & Freq. & Osun State \\
\hline & & Percentage & & Percentage \\
\hline From ADP & 10 & 12.5 & 25 & 31.3 \\
\hline Ministry of Agriculture & 10 & 12.5 & 15 & 18.75 \\
\hline Private Sources & 60 & 75.0 & 40 & 50.0 \\
\hline
\end{tabular}

The result in table 6 shows that over $50 \%$ of the farmers get fertilizer/pesticides from private sources. Farmers in both states complain that when the stock of the inputs are supplied few respondents get from ADP/Ministry of Agriculture stores. They are deprived from getting them (the inputs). This may be a reason for the poor farmers harvest adduced by Taiye (1994). A larger proportion of the farmers obtain their inputs from private sources.
From Table 7, it is clear that no meaningful capital project was carried out by both states ADP other than the maintenance of already existing ones. Most infrastructure of Osun State ADP were within Iwo zone. Both ADP's encourage irrigation farming with higher proportion in Edo State.

Table 7: $\quad$ Effect of ADP in relation to infrastructure supply to farmers enclave community in Edo and Osun State

\begin{tabular}{|l|l|l|l|l|}
\hline Infrastructure & \multicolumn{2}{|c|}{ Edo State } & \multicolumn{2}{c|}{ Osun State } \\
& Frequency & Percentage & \multicolumn{2}{l|}{ Frequency } \\
\hline Earth roads constructed & - & - & - & - \\
\hline Earth roads maintained & 50 & 62.5 & 70 & 87.5 \\
\hline Borehole water scheme provided & 30 & - & - & 56.3 \\
\hline old boreholes maintained & & & & \\
\hline $\begin{array}{l}\text { FADAMA (Irrigation farming) } \\
\text { in Oyo State }\end{array}$ & 65 & 81.3 & 50 & 62.5 \\
\hline Storage Facilities by ADP & - & - & - & - \\
\hline Fishers constructed by ADP & - & - & - & - \\
\hline
\end{tabular}

Table 8: T - Test Analysis for Extension Services of ADPs Farmers in OSun and Edo States

\begin{tabular}{|l|l|l|l|l|l|l|l|l|}
\hline Variable & $\begin{array}{l}\text { No of } \\
\text { Cases }\end{array}$ & Mean & $\begin{array}{l}\text { Standard } \\
\text { Deviation }\end{array}$ & $\begin{array}{l}\text { Standard } \\
\text { Error }\end{array}$ & $\begin{array}{l}\text { Mean } \\
\text { Difference }\end{array}$ & $\begin{array}{l}\text { T- } \\
\text { Test }\end{array}$ & $\begin{array}{l}\text { P } \\
\text { value }\end{array}$ & $\begin{array}{l}\text { Decision } \\
\text { Edo }\end{array}$ \\
Osun & 80 & 20.94 & 3.91 & 0.43 & 0.11 & 3.17 & 0.43 & NS \\
\hline
\end{tabular}

NS = Not Significant at 0.05

Table 8 shows that there is no significant difference extension services of ADPs farmers in the two states $(\mathrm{t}=3.17, \mathrm{P}-0.43)$

\section{RECOMMENDATIONS}

In the light of the above findings, the following recommendations are made
1. The state ADP should recruit enough extension workers to enable every farmer in the rural areas benefit from new research findings.

2. More farm services centres should be established to hire or purchase improved inputs.

3. The local government councils should be encouraged to provide small-scale modern 
processing and storage facilities. They should be established in designated villages in order to prevent produce from wasting.

\section{REFERENCES}

Adegeye, A. J. and Dittoh, J. S (1985). Essential of Agricultural Economics, Ibadan Impact Publishers, Ibadan

Adedipe, N. O. Okuneye, P. A. Idowu, I. A. and Adebayo, K (1995). Pre-service and in- service Extension Education in the University of Agriculture, Abeokuta, Nigeria. An FAO Study Report, 77p.

Adebayo, K and Idowu, T. A. (2000). The aftermath of the withdrawal of the World Bank counterpart funding for the Ogun State Agricultural Development Programme in Nigeria, Journal of Sustainable Agriculture Vol. 17 (2/3) pp. 79-93.

Bendel, ADP (1989). Bendel ADP/Farmers' Farm Programme, Bendel ADP, pp. 1 - 8.
Bola, A. (1993). A non technical paper delivered to farmers and extension workers at a client consultation workshop in Enugu and Kastina as apart of the appraisal of MATs. P. 11.

Egharevba, P. N. (1996). Food is the Sustainers of Life, Inaugural Lecture Series 44 University of Benin, Benin PP. 7.

Onaghise G. T. U. (1991). Impact of ADP in the agricultural scene of the state proceedings of the 7th Agric.Week Celebration of the national Association of Agricultural Students, University of Benin Chapter, Benin.

Osun ADP (1999). Annual Report. Bank Experience 1965 86. A World Bank Operations Evaluation Study. The World Bank, Washington, DC, 140p.

Taiye, A. A. (1994). The Nigerian Farmer, its Anxieties, Frustrations and Dilemma Implications for Development, I. A. R. \& T, Ibadan P. 5.

The World Bank (1995). Nigeria and the World Bank: Learning from the fast, looking to the future, The world Bank, Washington DC. 